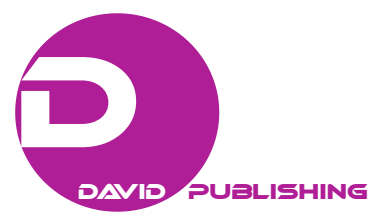

\title{
China and Russia on the Baltic Sea: Between Rivalry and Cooperation
}

\author{
Piotr Mickiewicz \\ University of Gdansk, Gdansk, Poland
}

\begin{abstract}
The Russian-Chinese cooperation conducted on sea basin conducted in the 21 st century is aimed at limiting the US ability to control global transport routes, especially energy transport carriers. The community of interests outlined in this way allows for undertaking a number of political and economic initiatives and the use of demonstration of strength in regions where the national interests of both countries are located. Its scope is limited by existing divergences, which particularly concern the European policy of both countries. Chinese plans to build the One Belt One Road transport system are violating the status quo in Eurasia in favour of Beijing. While under the Asian policy both countries have managed to reach a compromise regarding the way of economic activity and the formula for building this merger, the scale of divergence of interests in Europe limits the possibility of reaching a similar agreement. Russia's goal is primarily to limit the US's ability to control northern shipping routes, followed by maintaining political and economic influence in Europe in the context of China's increasing activity and the gradual decrease in the demand for energy resources. For China, the goal is to make the most effective use of the transport system to Europe, ultimately based on the One Belt One Road project. Therefore, the only common strategic goals of both countries in relation to Europe are striving to transfer the burden of US maritime activity from Asian reservoirs to the waters of the Artic and North Atlantic the seas surrounding Europe. However, the Chinese from this group exclude the Baltic Sea, which is to be an area of political stability. However, in the assumptions of Russian policy, the Baltic is to be a substitute region for conducting Arctic rivalry. The existing discrepancies mean that the scope of European cooperation of both countries is limited and will focus on limiting the American dominance on maritime shipping routes and economic undertakings enabling the realization of the interests of both countries.
\end{abstract}

Keywords: Russia, China, Baltic Sea, maritime policy, cooperation

\section{Introduction}

The economic and political transformations of the first decade of the 21 st century led to significant changes in the policy of China and Russia. The development ones adopted in their result meant that both countries had to make a significant transformation of their own economies. It was connected with the necessity to redefine the role and character of the conducted trade exchange and the significance of trade routes. These concepts were presented in various strategic documents, but their common feature was the priority treatment of trade exchange carried out by sea, recognition of the role of the global energy trading system as one of the most important factors creating development processes. The developmental role of the import of technologies,

Piotr Mickiewicz, Ph.D., Professor, Institute of Political Sciences, University of Gdansk, Gdansk, Poland. 
semi-finished products, and technological raw materials was also noticed, which further increased the importance of sea communication routes in the policy of both countries (Government of the Russian Federation, 2003, Part I; Government of the Russian Federation, 2009, Part I, Part IV, p. 2, Part V; Russian Academy of National Economy, 2010, T.II Part 16; State Council of the People's Republic of China, 2015b, s. 2-4; State Council of the People's Republic of China, 2006, Part I, Part II; State Council of the People's Republic of China, 2015a, pp. 3-4). This assumption defined the scope of possible Russian-Chinese cooperation, which was the result of a limited community of interests in the process of obtaining the super-petrostate status ${ }^{1}$. The area of cooperation was marked by two factors in the form of the necessary limitation of the US ability to control regions for the extraction and transport of energy resources, which both countries regard as the most serious threat to their security and ensure continuity of supply and "economic ties" of selected regions. In Russian policy, the goal is to link energy importing countries, while China's policy is focused on building advanced economic and political contacts with exporters of energy and technological resources, as well as potential importers of mass and high-tech production. In contrast, the fields of potential conflicts determine:

- geographical location of potential importers and exporters of energy resources in the regions of location of vital interests of both powers;

- the scale and nature of mutual economic cooperation enabling the political and economic dominance of the partner (the scale of Chinese investments in Russia and the volume of energy imports);

- different vision of the super-petrostate status and the resulting concept of achieving this status;

- the importance of American neo-naval (US Navy, Chief on Naval Operations, 2006; Department of Navy, US Coast Guard, 2016) $)^{2}$ policy for the level of economic security in both countries.

\section{Political and Economic Conditions of Russian-Chinese Cooperation in Sea Areas}

The scope of the Russian-Chinese cooperation on sea waters is determined by three issues. The first is China's pursuit of the status of a US maritime player equivalent to the Pacific and Indian Ocean (Preston, Bailey, Bradley, Wei, \& Zhao, 2016, pp. 8-9)3. The second should be the issue of Russian economic security, which was defined as the ability to exploit new deposits of energy resources in the Arctic shelf and export energy carriers at a level that allows the implementation of state development processes (President of Russia, 2017, Part II, points 14-15, Part III, p, 20; President of Russia 2019, points 22, 27). The third is to gain the ability to control areas of trade exchange under the One Belt One Road project, which requires a maritime presence in the Red, Mediterranean, and Baltic Seas, and ultimately the Antarctic Ocean. The nature and

\footnotetext{
1 The author defines the concept of super-petrostate as a country which development and political position depends on the trading of energy carriers, but at the same time is resistant to fluctuations in the market for their trading and has the ability to partially create the way this market functions.

2 The author uses this concept to define the American vision of using the armed forces and conducting point expansion. This applies in particular to the US's ability to conduct political and military operations in two regions for a minimum of six months, or political and economic operations protected by military potential, as well as the ability to base and transfer forces to any region of the world. The formula of the activities carried out was to ensure the United States control of the freight system through maritime presence at nodal points of global trade. In the first decade of the 21 st century, they were located mainly in the Indian and Pacific oceans and the Mediterranean, Arabian, and Black Seas (the Ormuz Bab del Mandab strait, Malacca, Bosporus, and Dardanelles, as well as the Suez and Panama canals). Successively, in the second decade of the 21 st century, the important of the Antarctic Ocean waters with the Bering Strait and the Baltic, Caspian, and Azov Seas increased.

3 According to economic estimates, in 2020, China will import as much as 39 of 45 minerals necessary for the economy, including as much as $70 \%$ of crude oil. The group of the most important exporting countries are overseas countries, such as Australia, Persian Gulf countries (Saudi Arabia, Iran, Oman, Iraq, United Arab Emirates), Africa (Angola, South Africa), and both Americas (Brazil, Chile, Venezuela, the USA, and Canada).
} 
intensity of cooperation in maritime waters have been determined by the capabilities of both countries to control the necessary to ensure their economic security of sea waters. They will take the form of actions aimed at ensuring the possibility of conducting unrestricted navigation, including actions aimed at reflection of seized vessels and interruption of blockade activities (Chinamil, 2015b) ${ }^{4}$. It should also be assumed that episodes emphasizing the ability to enforce their national interests in sea depend on the shape of the interests of both countries in a given basin and in a way that allows for expanding influence in the region. Nevertheless, the most important political and economic determinant shaping the scope of Chinese-Russian cooperation in sea areas will be the One Belt One Road project and - to a lesser extent-the organization of the Russian energy exports to the so-called new (non-traditional) partners. Both projects require obtaining the ability to reside in specific sea areas; in the case of the One Belt One Road project the issue in the water will remain a contentious issue, these are mainly:

- the Antarctic Ocean with the Barents Sea forming the Polar Silk Road;

- the Baltic Sea which is to be part of the New Silk Road.

\section{The Baltic Region Policy-Cooperation or Rivalry}

China and Russia's Baltic policies are created by two processes: the way of implementation Polar Silk Road and US LNG gas exports to the countries of the region. The concept of the Arctic maritime connection from China to Europe (Polar Silk Road) presented in 2018 was supposed to be part of the newly constructed Chinese Arctic policy. In 2013-2018, it was limited to three goals, the most important of which was to respond to attempts to obtain the status of Arctic player by Japan and South Korea ${ }^{5}$. Less importance was then attached to the possibilities of cooperation with Russia, considering that investments in the process of exploiting Siberian deposits, for strategic reasons, should be focused on land transport ${ }^{6}$. The change in this policy that took place in 2018 is the result of two processes, which should be considered the opportunities offered by the export of Russian energy carriers of the Novatek Yamal LNG and Arctic LNG $2^{7}$ terminals and the Russian policy itself of using the north-west passage using the Northern Sea Route. The plans for the expansion of Siberian fuel and energy complexes require the supply of elements of mining, transmission, and processing infrastructure by sea, also from outside the Federation. Thus, Russia is forced to accept the very right to navigate this route of trade vessels bearing the flag of other countries. For this reason, it limits-in relations to solutions applied by Canada to the rules of Northwest Passage route flow-the scope of regulations regarding the flow of this route to fulfil specific administrative obligations and the application of a tariff for specific navigation and sailing services, including the obligation to use the services of Russian icebreakers.

Recognition by the US of Poland as the most important strategic recipient of LNG caused that Russia was forced to open the Baltic Sea basin for the Chinese war fleet. The consequence of joint maritime manoeuvres carried out in 2017 is, de facto, recognition by Moscow of Chinese trade interests in Europe (Sputnik, 2017). The Baltic, which was to be, according to the assumptions of the sea doctrine, a sea under the full control of the

\footnotetext{
${ }^{4}$ An example of this type of activity was Russian-Chinese exercises codenamed Joint Sea (17-21.05.2015). Using the anti-piracy coalition, the Russians and Chinese carried them out in the Mediterranean. They also took the formula of actions aimed at protecting maritime units, as they were focused on escorting and repelling pirate attacks.

5 These countries announced the assumptions of their Arctic policy in the years 2013 and 2015.

6 The promoted WSTO project enabled obtaining supplies from a Central Asian country and provided China with the ability to control Russian supplies to South Korea and Japan.

7 Especially since the Chinese concerns are the owner of $30 \%$ of shares in these enterprises and import about four million tonnes of LNG produced in them.
} 
Russian Baltic Fleet, was included in the Chinese plan to build efficient, safe, and effective transport routes, including those connecting the most important sea ports (China National Development and Reform Commission, 2015, Part III Framework) $)^{8}$. The inclusion of the Baltic Sea as an element of the Silk Road should be considered one of the crisis-making decisions in the mutual relations of both countries. The shape of the Baltic transport routes is determined by political objectives in relation to the partner and in the regional and global dimension. The main factor creating potential threats to Chinese-Russian cooperation is the issue of including Russian imports as well as internal trade in goods in the Silk Road transport system. This solution increases the economic efficiency of Asia-Europe rail connections and limits the scope of opening the Chinese market to exports of goods from Europe. However, at the same time, it leads to an increase in the dependence of the way these connections operate from Russia, which changes the relationship between China and Russia do the detriment of China. It also eliminates, from Beijing's point of view, the scope of potential cooperation with the countries of Central and Eastern Europe under the $16+1$ formula ${ }^{9}$. Countries which, due to their geographical location and economic potential, play the role of regional leaders of the Silk Road project in Chinese assumptions are Poland, Hungary, and Romania. The positive reaction, especially of Poland (Polish Silk Road) (Biznesalert, 2018) ${ }^{10}$ meant that Russia's goal is to force China to correct the route of the Trail and carry it across the Baltic. The Russians mainly emphasize the need to include the Baltic ports as transhipment hubs and Silk Road logistics centres. This policy is positively supported by Estonia and the Federal Republic of Germany, although for Germany, an alternative solution may be a land connection via Łódź to Duisburg. The above conditions determined the formula of China's Baltic policy, and thus the areas of Russian-Chinese rivalry and cooperation in the regional dimension. For China's export policy, the Federal Republic of Germany remains the principal partner as a place of export supply to the European Union market. The main role of the Logistics Centre Duisburg $A G$ as a place for the redistribution of goods and the scale of exports to Scandinavia and Great Britain determines the extent of Chinese involvement in the Baltic region. The optimal solution is to use Poland as a transit country and Łódź logistics centre together with container terminals in Gdańsk and Gdynia, but also in correlation with the functioning and planned rail connections of the Nordic countries. This solution ensures the transhipment efficiency of the main sea and land hubs of the European Union (Duisburg,

\footnotetext{
8 The Belt and Road run through the continents of Asia, Europe, and Africa, connecting the vibrant East Asia economic circle at one end and developed European economic circle at the other, and encompassing countries with huge potential for economic development. The Silk Road Economic Belt focuses on bringing together China, Central Asia, Russia, and Europe (the Baltic); linking China with the Persian Gulf and the Mediterranean Sea through Central Asia and West Asia; and connecting China with Southeast Asia, South Asia, and the Indian Ocean. The 21st-Century Maritime Silk Road is designed to go from China's coast to Europe through the South China Sea and the Indian Ocean in one route, and from China's coast through the South China Sea to the South Pacific in the other. [...]At sea, the Initiative will focus on jointly building smooth, secure, and efficient transport routes connecting major sea ports along the Belt and Road.

${ }^{9}$ This cooperation formula has been in operation since 2012 and is created by the PRC and Estonia, Latvia, Lithuania, Poland, the Czech Republic, Slovakia, Hungary, Romania, Bulgaria, Slovenia, Croatia, Serbia, Bosnia and Herzegovina, Montenegro, Albania, and Macedonia. For Beijing, initially the economic goal was increasing investment involvement, but since 2015 the goal is to implement the Silk Road project. Among the countries of the region interested in the significant involvement of China are Hungary and Serbia, Romania, and from the Baltic States: Estonia and Poland.

10 The scale of Polish involvement in the implementation of the project can be proved by the calendar of meetings and statements of representatives of political authorities. In 2015-2018, visits to China, during which talks were held about Polish participation in this project, were visited by President Duda (2015) and the then Prime Minister, Beata Szydło (2017). The purposes of adjusting the investment into the logistics and transport system to the Path project were indicated by both the then Prime Minister M. Morawiecki, and the Deputy Minister in the Development Ministry P. Chorąży, while the present Minister of Infrastructure A. Adamczyk emphasizes the convergence of this project with the Polish interests. A similar position is taken by a Polish member of the Board of Directors of the Asian Bank for Infrastructure Investments Radosław Pyffel.
} 
Rotterdam, Amsterdam, Hamburg), and in relation to exports to the Nordic countries, also allows reducing the delivery time. The alternative in the form of the use of eastern Baltic ports, especially the Russian ones, located in the Gulf of Finland or the ports of Estonia and Latvia (and ultimately the extended port in Kaliningrad), is justified only in the context of using them for transport by German-Russian motorways of the sea (to Rostock and Sassnitz-Mukran). As a consequence, the ports of Hamburg and Bremen as well as the Duisburg logistics centre will remain the main transhipment hubs. Therefore, the above situation is treated in China as an alternative, and Russia considers it to be the target. In this arrangement of transport lines, China will have to accept the use of Russian transport systems (Trans-Siberian railway) and adapt the Silk Road threat system to the shape of Russian internal trade in goods. This also creates the potential need to accept them in a way that allows the use of Russian ports as transhipment and distribution locations for Chinese exports. The negative of this solution is the need to accept Russian interests in Europe, especially in the Black Sea catchment area and Central Europe. It also requires Beijing to refer to the way Russia conducts its policy towards Ukraine, Georgia, and Poland. In practice, this may lead to the abandonment of one of the alternative Silk Road routes, i.e., the route through southern Kazakhstan, Azerbaijan, Georgia (Poti port), Ukraine (Odessa port), and Kiev to Łódź. It is rather a project intended to weaken Russia's position in the consortium implementing the One Belt One Road project, rather than a real option. However, it is an important instrument of influence and must therefore remain in Chinese concepts as potential scenarios for action.

In Russian policy, the way of using national transport systems and - in addition - port infrastructure on the Baltic Sea is treated as a means to deepen the scope of bilateral cooperation with China and the Federal Republic of Germany. By emphasizing this community of interests with Beijing, they seek to dominate the Baltic transport system. However, in Russian policy, Germany is perceived as a state - a distributor of Russian energy resources to the EU and imports of technological equipment components to Russia, necessary to modernize the fuel and energy sector. The essence of Russian activities is therefore to create ventures that allow the expansion of transmission systems in the EU and their integration with Nord Stream and bypass the Central Europe region as a transit area. An attempt to transfer this exchange from land areas to the Baltic Sea, by using the Baltic ports of the Federal Republic of Germany and the motorways of the Rostock and Sasnitz-Mukran Seas, and Russian ports, however, is contrary to Chinese Baltic projects ${ }^{11}$. The presented conditions mean that there is more competition than cooperation between Beijing and Moscow in the Baltic region. This region is not a place of conducting joint economic initiatives or investments. In fact, based on the Chinese analysis of investment activity in Europe, it can be stated that some of them are aimed at limiting the need to conduct joint Chinese-Russian ventures. Beijing has an independent investment policy in Europe, which has been focused on European economic and political powers (Germany, Great Britain, France) and countries important for the shape of trade (Norway, Sweden, Poland, Finland, Italy, Greece, Hungary). Investment activity, with the exception of Poland, was focused on such spheres of the economy as the municipal services sector, transport, infrastructure, energy, and the machinery industry. In the case of Poland, after the fiasco of the concept of

11 The leading undertaking is the so-called Maritime Motorways, which are to run between the Baltic ports of Germany [Sassnitz-Mukran, Rostock] and the Russian ports [Bałtijsk and Kaliningrad, Ust'Ługa, St. Petersburg]. The transhipment centre in the Maritime Motorways system is the port of Sassnitz due to its transhipment infrastructure. It is adapted to the service of Russian rail track sets, and the investments carried out jointly by Russian Railways and Deutsche Bahn for investments in the ferry-rail transport system Bałtijsk-Sassnitz, allow handling of wheel reloading up to 6.5 million tonnes per year. The support, in relations to the ro-ro cargo, is the Rostock port and a number of investments in the wheel-rail communication system, especially in North Rhine Westphalia. 
investment in the construction of transport systems, freight traffic in ports is the leading sphere. You can even indicate areas of competition that focuses on the possibility of choosing alternative to Russian transport routes. The most important, specific fields of competition are the China-Europe Land-Sea Express ${ }^{12}$ project and the China's policy towards Silk Road. The first of these projects does not include the Baltic region, while the second one is to eventually connect Odessa with the Baltic ports, and the scope of cooperation between Beijing and Kiev includes a number of projects, including investments in Ukraine and various cooperation initiatives of the economic representations of both countries. However, while in 2016 the decisions on the intensification of economic cooperation between the PRC and Ukraine were announced, the content of talks and conclusions of the special Chinese-Ukrainian forum was not disclosed in 2017 (it was held on November 16, 2017). China's policy with regard to both projects can be described as instrumental. It also indirectly proves that Beijing's creation of Asia-Europe connections alternative to Russian land connections is used to reduce Russia's position in shaping the route and the way the Northern Silk Road functions.

\section{Summary}

Chinese-Russia cooperation on maritime waters is shaped by geopolitical factor and global political and economic goals. The main reason is to ensure continuity of supply by sea, mainly energy carriers, and expanding export opportunities. It also allows achieving partial goals in relation to actions aimed at weakening the US position in global sea basins. The joint activity of naval forces on the seas surrounding the European continent forces the increased activity of the American fleet in these waters. This indirectly limits its activity in the Pacific reservoirs, i.e., areas of implementation of China's national interests. To a lesser extent, this applies to the American presence in the Arctic waters, but it is offset by the Russian policy of creating air and sea incidents in the North Atlantic, as well as the North and Baltic Seas. The solution which, in Russian concepts, is to limit the possible reactions of the US and its allies (mainly Great Britain and Canada) is the presence of coalition naval forces in these waters. However, maritime activity in these waters is not a priority for China, which has modified Russia's policy. Russia has attempted to transfer this form of influence to the Baltic Sea, an important area for Beijing. However, the presence of Chinese naval forces is temporary and limited to joint exercises. Beijing will not be able to permanently station its own fleet in this region, which means that it is not interested in creating political tensions that limit the possibility of conducting export expansion. Thus, the political goal will remain to stabilize the situation in the region, also providing for limiting the American presence and the possibility of creating a political situation. In addition, it allows controlling Russian maritime activity, which is treated as one of the creators of export policy and economic expansion. Therefore, it should be recognized that the factor determining Chinese presence in European waters is the awareness of the difference in potential between the US fleets and the Chinese Navy. As noted above, obtaining the potential for global activity and obtaining the status of a global maritime power is possible by increasing the potential of naval forces and obtaining the ability to be stations in selected sea areas. The Chinese gain a significant part of these opportunities through cooperation with Russia. Transferring the rivalry from the USA to a reservoir that does not play a significant role for Chinese interests (outside the Pacific, the Indian Ocean, the Arabian Sea, and the Eastern Mediterranean) is also of considerable importance. Thanks to cooperation with Russia, they can mean the weight of American efforts to focus on the North Atlantic and Northern Europe's waters and the

12 The project assumes the intermodal connection of Alexandria-Piraeus and rail to Budapest via Serbia. 
western Arctic Ocean, i.e., in the distance from the most important Asian waters for their interests. At the same time, including Russia in various forms of activity in the Pacific causes a kind of internationalization of its operations, which eliminates the accusation of attempts to appropriate these waters. It also limits the possibility of reaction, competing with China for their control and inclusion of the countries of the region in its Exclusive Economic Zone. For the Russians, this cooperation allows them to gain the ability to contribute to the situation in regions of potential exports of processed energy resources and to obtain political and military support for projects carried out in the Arctic basins. It is obtained at the expense of acceptance of the Chinese presence in the most important European sea basin for Beijing, i.e., the Baltic Sea. However, this presence is incidental and depends on the nature of the political and military cooperation of both countries. However, it allows China to achieve its strategic goals in relation to Northern Europe. When assessing the effectiveness of joint ventures between China and Russia on maritime waters, it should be acknowledged that they allow limiting American dominance and enabling the realization of maritime interests of both countries. They are not always convergent, and the difference in potential means that the beneficiary of this cooperation is China, to a greater extent. This leads to various forms of confrontation between the two partners and forces them to pursue individual policies in specific subject and geographical areas.

\section{References}

Biznesalert. (2018). Polish Silk Road (Raport Polski Jedwabny Szlak). Biznes Alert z 18.03.2018. Retrieved from https://biznesalert.pl/nowy-jedwabny-szlak

Chinamil. (2015a). China-Russia joint naval exercise legitimate and normal. J. N. Yao, (Ed.). Retrieved from http://eng.chinamil.com.cn/special-reports/2015-05/14/content_6491424.htm

Chinamil. (2015b). Naval interaction 2015, China, Russia joint maritime exercise, May 11 to 21, 2015. Retrieved from http://eng.chinamil.com.cn/special-reports/node_77649.htm

Chinamil. (2019). Russia, China to conduct joint naval drills in Late April-Early May. Retrieved from http://eng.chinamil.com.cn/view/2019-03/27/content_9460385.htm

China National Development and Reform Commission. (2015). Vision and actions on jointly building Silk Road Economic Belt and 21st-Century Maritime Silk Road. Issued by the National Development and Reform Commission, Ministry of Foreign Affairs, and Ministry of Commerce of the People's Republic of China, with State Council Authorization, March 28, 2015. Retrieved from http://en.ndrc.gov.cn/newsrelease/201503/t20150330_669367.html

Department of Navy, US Coast Guard. (2016). A cooperative strategy for 21st century sea power. Retrieved from https://www.navy.mil/local/maritime/150227-CS21R-Final.pdf (March 2015)

Government of the Russian Federation. (2003). Russian energy strategy until 2020 (Распоряжение Правительства Российской Федерации Об утверждении Энергетической стратегии России на период до 2020 года от 28 августа 2003 года N 1234-p). Retrieved from http://docs.cntd.ru/document/901872984

Government of the Russian Federation. (2009). Russian energy strategy until 2030 (Распоряжение Правительства Российской Федерации Об утверждении Энергетической стратегии России на период до 2030 года13 ноября 2009 г. № 1715 -р). Retrieved from http://www.infobio.ru/sites/default/files/Energostrategiya-2030.pdf

President of Russia. (2017). Russian federation economic security strategy until 2030 (Указ Президента РФ от 13 мая 2017 г. N 208 “О Стратегии экономической безопасности Российской Федерации на период до 2030 года”). Retrieved from http://kremlin.ru/acts/bank/41921

President of Russia. (2019). Security energy doctrine (Указ Президента РФ от 13 мая 2019г. №216 “Об утверждении Доктрины энергетической безопасности Российской Федерации”). Retrieved from https://www.garant.ru/hotlaw/federal/1272523/

Preston, F., Bailey, R., Bradley, S., Wei, J. G., \& Zhao, C. W. (2016). Navigating the new normal. China and global resource governance. A Joint DRC and Chatham House Report, 2016. Retrieved from https:/www.chathamhouse.org/sites/default/files/publications/research/2016-01-27-china-global-resource-governance-presto n-bailey-bradley-wei-zhao-final.pdf 
Russian Academy of National Economy. (2010). Strategy 2020 (Стратегия-2020: Новая модель роста-новая социальная политика. Промежуточный доклад о результатах экспертной работы по актуальным проблемам социально-экономической стратегии России на период до 2020 года). Retrieved from https://www.hse.ru/strategy2020

Sputnik. (2017). Putin: Rosja uwzględni interesy Chin. Sputnik 11.1.2017. Retrieved from https://pl.sputniknews.com/gospodarka/201711116686029-Putin-Rosja-Chiny-Sputnik/

State Council of the People's Republic of China. (2006). China's national defense in 2006. The Information Office of the State Council People's Republic of China, December 29, 2006. Retrieved from https://fas.org/nuke/guide/china/doctrine/wp2006.html

State Council of the People's Republic of China. (2015a). China's Military Strategy. The State Council Information Office of the People's Republic of China, May 2015, Beijing. Retrieved from http://english.www.gov.cn/archive/white_paper/2015/05/27/content_281475115610833.htm

State Council of the People's Republic of China. (2015b). Made in China 2025. State Council, July 7, 2015. Retrieved from http://www.cittadellascienza.it/cina/wp-content/uploads/2017/02/IoT-ONE-Made-in-China-2025.pdf

State Council of the People's Republic of China. (2018). China's arctic policy. The State Council Information Office of the $\begin{array}{llllll}\text { People's Republic } & \text { of } & \text { China, } & \text { January }\end{array}$ http://english.gov.cn/archive/white_paper/2018/01/26/content_281476026660336.htm

US Navy, Chief on Naval Operations. (2006, May). Navy strategic plan in support of program objective memorandum 08. Retrieved from http://edocs.nps.edu/2014/May/NSP-POM08.pdf 